\title{
Knowledge of HIV and benefits of male medical circumcision amongst clients in an urban area
}

\begin{abstract}
Author:
Abidemi Faleye ${ }^{1}$

Affiliation:

${ }^{1}$ Department of Family

Medicine, University of

KwaZulu-Natal, Durban,

South Africa

Correspondence to:

Abidemi Faleye

Email:

abidemi.faleye@gmail.com

Postal address:

PO Box 33093, Montclair

4061, South Africa

\section{Dates:}

Received: 21 May 2014

Accepted: 14 Aug. 2014

Published: 11 Dec. 2014

How to cite this article

Faleye A. Knowledge of HIV and benefits of male medical circumcision amongst clients presenting for circumcision in an urban area. Afr J Prm Health Care Fam Med. 2014;6(1), Art. \#722, 5 pages. http://dx.doi.org/10.4102/ phcfm.v6i1.722

\section{Copyright:}

(C) 2014. The Authors. Licensee: AOSIS

OpenJournals. This work is licensed under the Creative Commons Attribution License.
\end{abstract}

Read online:
Background: Male medical circumcision (MMC) has been shown to reduce the risk of HIV transmission in circumcised men by up to $60 \%$. Following recommendations from the World Health Organization, South Africa adopted MMC as a preventative strategy against HIV in 2010 and set up circumcision camps across the country. Concerns have been raised about condom avoidance following MMC because of a mistaken belief about the benefits of MMC.

Aim and setting: The aim of this study was to describe the profile and knowledge about HIV and circumcision amongst men presenting for MMC in an urban area in KwaZulu-Natal.

Methods: This was a cross-sectional descriptive study of 394 clients over the age of 18 years who presented to two MMC sites in Durban between November 2012 and March 2013. A validated questionnaire was used to collect data.

Results: The mean age of clients presenting for MMC was 28 years. Most clients were black, single, unemployed and sexually active. The majority presented for MMC because they believed that MMC would reduce their risk of acquiring HIV infection. Knowledge about HIV transmission was very good and $86.3 \%$ of clients were aware that risky sexual behaviour such as condom avoidance could reverse the benefits of MMC.

Conclusion: The knowledge of HIV and benefits of MMC was very good amongst those presenting for MMC. However as MMC is primarily a preventative strategy, innovative methods to promote MMC prior to first sexual encounter need to be explored. Further research is needed to determine whether the benefits of MMC on the reduction of HIV transmission are sustained in routine practice.

La connaissance du VIH et les bienfaits de la circoncision médicale masculine chez les clients qui se présentent pour la circoncision dans les zones urbaines.

Contexte: Il a été démontré que la circoncision médicale masculine (MMC) réduit de $60 \%$ les risques de transmission du VIH chez les hommes circoncis. A la suite des recommandations de l'Organisation mondiale de la Santé, l'Afrique du Sud a adopté en 2010 la MMC comme stratégie de prévention contre le VIH et établi des camps de circoncision dans tout le pays. On a montré de l'inquiétude sur la non utilisation de préservatifs suite à la MMC due aux idées fausses sur les bienfaits de la MMC.

Objectif et cadre: Cette étude avait pour but de décrire le profil et les connaissances sur le VIH et la circoncision chez les homes qui se présentent pour la MMC dans une zone urbaine du Kwa Zulu Natal.

Méthodes: Ceci était une étude transversale descriptive de 394 clients de plus de 18 ans qui se sont présentés à deux services de la MMC à Durban de novembre 2012 à mars 2013. On s'est servi d'un questionnaire validé pour collecter les données.

Résultats: L'âge moyen des clients se présentant pour la MMC était 28 ans. La plupart des clients étaient noirs, célibataires, chômeurs et actifs sexuellement. La majorité se présentaient pour la MMC parce qu'ils croyaient que la MMC réduirait le risque d'être infecté par le VIH. Ils étaient bien au courant de la transmission du VIH et $86.3 \%$ des clients savaient que les comportement sexuels risqués tel que la non utilisation des préservatifs pouvaient annuler les bienfaits de la MMC.

Conclusion: Les hommes qui se présentaient pour la MMC avaient une bonne connaissance du VIH et des bienfaits de la MMC. Cependant, étant donné que la MMC est en premier lieu une stratégie de prévention, il faut trouver des méthodes innovatrices pour promouvoir la MMC avant la première relation sexuelle. Il faut faire des recherches supplémentaires pour déterminer si les bienfaits de la MMC sur la réduction de la transmission du VIH sont durables dans la pratique quotidienne. 


\section{Introduction}

Currently, 2.3 million new HIV infections occur each year and 35.3 million people worldwide are living with HIV. ${ }^{1}$ With such large numbers of people infected with HIV, prevention and treatment of HIV are an international priority. New prevention strategies such as male medical circumcision (MMC), use of vaginal microbicides, pre-exposure prophylaxis with antiretroviral agents, herpes suppressive therapy, cervical barrier methods, HIV vaccines and early initiation of antiretroviral therapy are all being promoted as potential methods for the reduction of HIV transmission. ${ }^{2}$

Male medical circumcision (MMC) is the surgical removal of the prepuce from the glans of a flaccid penis. Epidemiological studies have shown a geographical correlation between male circumcision and HIV prevalence, with countries that traditionally practise male circumcision having lower rates of HIV prevalence than countries that do not. ${ }^{3,4}$ Three randomised controlled trials done in South Africa (SA), Kenya and Uganda in 2005 and 2007 showed that MMC reduced HIV transmission in circumcised men by $60 \%$, 53\% and $51 \%$, respectively. ${ }^{5,6,7}$ This reduction in HIV transmission results from the removal of the prepuce which contains a large number of Langerhans cells. These cells are immunological in nature and are rich in CD4 cells, making them a target for HIV entry and replication. ${ }^{3}$ In addition, MMC has been shown to protect circumcised men from ulcerative sexuallytransmitted infections (STIs) ${ }^{6,7}$ such as Herpes simplex virus type 2 (HSV-2), which predisposes one to HIV infection, as well as against human papilloma virus (HPV) infections. ${ }^{8}$ The reduced incidence of HPV infection in circumcised men has resulted in the reduction of penile carcinoma amongst circumcised men and indirectly protects women against cervical cancer. ${ }^{9,10,11}$ MMC has also been noted to lead to a reduced risk of prostate carcinoma, less inflammation and infection of the skin of the penis and better genital hygiene. ${ }^{12}$ A number of African studies have shown MMC to be an acceptable intervention with high levels of uptake., ${ }^{3,5}$

In 2007, based on the evidence of these studies, an expert consultative forum of the WHO/UNAIDS (World Health Organization/Joint United Nations Programme on HIV/ AIDS) recommended that MMC be introduced in countries with a high prevalence of HIV and a low prevalence of male circumcision as part of the comprehensive HIV prevention package offered in these countries. ${ }^{2}$ As SA meets these criteria, MMC was adapted in 2010 as part of the national strategy for reducing HIV transmission. Since then, a large number of circumcision camps have been set up across SA in order to provide MMC services to males willing to be circumcised, with a target of circumcising $80 \%$ of uncircumcised men over a period of five years. ${ }^{13}$

However, concerns have been raised regarding the adaptation of the WHO recommendation and taking this strategy to scale in the South African context. Ncayiyane argues that the scientific evidence for large-scale roll out of MMC is insufficient to justify the energy, money and resources which have been devoted to the roll out of circumcision services. He further posits that the potential increase in risky behaviour based on the belief that circumcision prevents transmission of HIV, termed risk compensation, could nullify any gains from circumcision. ${ }^{14,15}$ This concern was supported by data from a 2003 study in the Westonaria district of SA which showed that $30 \%$ of circumcised men believed that they could safely have sex with many women without using condoms because they believed that circumcision prevented the transmission of HIV. ${ }^{15}$ However, in a study conducted in Johannesburg in 2010, Bridges showed that even though a section of the population found condom avoidance attractive post-circumcision, this risk was overstated in the 2003 study by Lagarde. ${ }^{16}$ In fact, a study done in Kenya in 2006, which examined attitude, beliefs and behaviour regarding HIV and MMC, showed that condom use went up in both circumcised and uncircumcised groups (i.e., control and experimental groups) following an intensive circumcision drive and this was linked to the counseling provided to men considering circumcision. ${ }^{17}$

Despite the concerns about condom avoidance in circumcised men, MMC is an important preventative intervention, as men who engage in risky sexual behaviour do not consistently use condoms and circumcision has been shown to lead to a significant reduction in the risk of HIV transmission in men. ${ }^{18}$ There is, however, a lack of information on the profile of men who access the MMC services in KwaZulu-Natal as well as their knowledge of HIV, their understanding of the benefits of MMC and their understanding of the importance of condom use post-MMC. This study aimed to address this gap and to make recommendations to the Department of Health regarding its circumcision campaign.

\section{Research methods and design Study design and setting}

This was a cross-sectional descriptive study carried out at Wentworth and St Aidan's Hospitals in Durban, KwaZuluNatal. Since March 2010, as part of the MMC roll-out programme, MatCH (Maternal Adolescent and Child Health) has been providing a free circumcision service to the population of Durban at Wentworth Hospital, St Aidan's Hospital and KwaMashu Polyclinic. Since the inception of the project, MatCH has run MMC educational programmes and recruitment drives in the townships around Durban and has provided free transport to the most convenient circumcision site. To date over 10000 clients have been circumcised at these sites.

\section{Study population and sampling strategy}

With up to 1000 clients presenting per month for MMC at Wentworth Hospital (WWH) in 2011, a sample of 400 clients representing $40 \%$ of those presenting in a month was considered sufficient for an observational descriptive study. ${ }^{19}$ Inclusion criteria were males 18 years or older presenting for MMC who agreed to participate in the study. There were no 
exclusion criteria. All clients who presented for MMC on the days that the research assistant was available were asked to participate in the study. No one who was approached refused to participate in the study. Prior to enrolment, patients were given an information sheet and informed consent was obtained by the research assistant. Data were collected prior to the MMC procedure using a questionnaire adapted from a validated questionnaire previously used by MatCH. ${ }^{20}$ Clients were asked to complete the questionnaire on their own and were assisted by the research assistant when necessary.

In October 2012, as a result of transport challenges associated with getting clients to $\mathrm{WWH}$, the number of men presenting at the hospital for MMC dwindled significantly. As $\mathrm{MatCH}$ is also responsible for the MMC programme based at St Aidan's Hospital, where more than 50 clients per day were presenting for $\mathrm{MMC}$, permission was requested from the ethics committee, the KwaZulu-Natal Department of Health and the hospital management to switch the study site from WWH and to gather data from St Aidan's from January 2013. Data were collected at WWH from November to December 2012 and from St Aidan's from January to March 2013.

\section{Data analysis}

Data were captured onto a Microsoft ${ }^{\circledR}$ Excel spreadsheet and analysed using the Statistical Package for Social Sciences (SPSS) version 21 (IBM Corp., Armonk, NY, 2012).

\section{Ethical considerations}

Approval for the study was given by the Biomedical Ethics Committee of the University of KwaZulu-Natal (reference number BE001/12), the hospital management and the KwaZulu-Natal Department of Health.

\section{Results}

Three hundred and ninety-four clients completed the questionnaires. Seventy-eight (19.8\%) were from WWH and 316 (80.2\%) from St Aidan's hospital. The mean age of clients was 28 years (standard deviation 8.67). The demographic profile of the participants is shown in Table 1.

The majority ( $n=210,53.3 \%$ ) of the clients came from local urban townships, with a few presenting from other districts. The majority had attended high school; over $60 \%$ $(n=324)$ were unemployed, most were single and sexually active.

The majority of clients presented for MMC because it offered partial protection against HIV with only 30 (7.6\%) having a circumcision because of social and/or religious reasons. Knowledge of transmission of HIV was excellent. Almost all of the clients had been counselled and tested for HIV and $85 \%(n=337)$ were HIV negative.

Most of the clients had a good understanding of the effects of MMC and the risk of acquisition of HIV and
TABLE 1: Demographic profile of clients $(N=394)$.

\begin{tabular}{|c|c|c|}
\hline Variable & Frequency & Percentage \\
\hline \multicolumn{3}{|l|}{ Race } \\
\hline Black people & 356 & 90.4 \\
\hline White people & 0 & 0.0 \\
\hline Indian & 21 & 5.3 \\
\hline Mixed race & 12 & 3.5 \\
\hline Missing & 5 & 0.8 \\
\hline \multicolumn{3}{|l|}{ Age } \\
\hline $18-30$ & 285 & 72.3 \\
\hline $31-43$ & 79 & 20.1 \\
\hline $44-56$ & 23 & 5.8 \\
\hline$>56$ & 7 & 1.8 \\
\hline \multicolumn{3}{|l|}{ Highest level of education } \\
\hline Never attended school & 8 & 2.0 \\
\hline Attended primary school (Grade 1-Grade 7) & 62 & 15.7 \\
\hline Attended high school (Grade 8-Grade 12) & 145 & 36.8 \\
\hline Passed Matric & 60 & 15.2 \\
\hline Post Matric training (either at college or university) & 119 & 30.2 \\
\hline \multicolumn{3}{|l|}{ Sexually active } \\
\hline Yes & 392 & 99.5 \\
\hline No & 2 & 0.5 \\
\hline \multicolumn{3}{|l|}{ Marital status } \\
\hline Single & 361 & 91.6 \\
\hline Married & 30 & 7.6 \\
\hline Widowed & 2 & 0.5 \\
\hline Divorced & 0 & 0.0 \\
\hline Missing & 1 & 0.3 \\
\hline \multicolumn{3}{|l|}{ Job status } \\
\hline Unemployed & 240 & 61.1 \\
\hline Employed & 153 & 38.9 \\
\hline Missing & 1 & 0.3 \\
\hline \multicolumn{3}{|l|}{ Area/Address } \\
\hline Urban & 154 & 39.9 \\
\hline Urban townships & 210 & 53.3 \\
\hline Urban informal & 19 & 4.8 \\
\hline Rural & 11 & 3.0 \\
\hline
\end{tabular}

understood that MMC is just part of the preventative package against HIV.

\section{Discussion}

The majority of those who participated in this study were in the 18-30 year age group (72.3\%), with an average age of 28 years as seen in Table 1 . These figures may have been distorted by the exclusion for ethical reasons of clients less than 18 years of age (109 clients were aged less than 18 years). However, these figures are consistent with a study by Connolly in 2005 which reported a similar age distribution in a national survey of MMC. ${ }^{21}$

Almost all of those who participated in this study (99.5\%) were sexually active. As MMC is intended to prevent HIV transmission it would be preferable to circumcise men prior to initiation of sexual relationships, especially in a society with a high prevalence of HIV. Pre-pubertal circumcision has been associated with the greatest reduction in the risk of HIV acquisition. ${ }^{22}$ Although the age of circumcision varies with race, tribe and religion, ${ }^{14,15}$ local studies are needed in order to determine the ideal age for MMC and to assess the 
acceptability of neonatal circumcision as a strategy for the prevention of HIV in SA.

The majority of those who participated in this study cited partial protection against HIV and personal hygiene as their reasons for seeking circumcision, as depicted in Table 2. Surprisingly, social and/or religious and cultural reasons accounted for less than $8 \%$ of the participants. This was unexpected, as in 2007 King Zwelithini stated that circumcision was a well-established Zulu cultural practice and that all young men should be circumcised. ${ }^{23}$

In keeping with a Namibian study done in $2010,{ }^{24}$ most clients had excellent knowledge of HIV, its transmission and benefits of circumcision. These men were aware that MMC provides only partial protection, that condoms are still needed to prevent HIV and that the benefits of MMC could be reversed if other protective lifestyle choices such as condom use are not adhered to (Tables 2 and 3). This is encouraging, as it suggests that HIV-related knowledge and the benefits of circumcision are reaching the target population. Recent findings have shown a significant drop in HIV prevalence in SA, which may suggest that not only is knowledge better but that HIV prevention messages are having an effect on sexual practices. ${ }^{25}$

MMC has been shown to reduce the risk of HIV transmission from men to women. Although most of those who participated in this study believed that circumcision does not protect women from being infected with HIV (Table 3), Alsallaq found that by reducing the pool of HIV-positive men, circumcision can indirectly protect women from HIV infection. ${ }^{26}$ This information appears to be lacking and could be used as another reason for men to consider circumcision.

Just over $13.2 \%$ of those who participated in this study were HIV-positive (Table 2). Initial Department of Health guidelines recommended MMC only for men who were HIV negative. However, the WHO currently recommends MMC for HIV-positive men for medical indications and because of the possible reduction in risk of transmitting $\mathrm{HIV}$ in those already infected with HIV. ${ }^{2}$ HIV-positive men also benefit from the reduced risk of ulcerative STIs which is associated with MMC. ${ }^{7}$ In 2012, the Department of Health updated its guidelines and currently recommends MMC in HIV-positive men if their CD4 is above 350 cells $/ \mathrm{mm}^{3}$, as studies have shown good wound healing at such CD4 levels. ${ }^{7}$ Currently, most of the HIV treatment programmes across SA have more women than men on treatment. ${ }^{27,28}$ This may be because women tend to access healthcare services more often than men and have more opportunities for testing than men (during antenatal care, when presenting at a clinic with a sick child, etc.). ${ }^{27,28}$ There is a need to find innovative ways to encourage men to test for HIV and for those who are positive to participate in treatment programmes. With the ambitious target of reaching $80 \%$ of uncircumcised men, the MMC programme may present such an opportunity for testing and for channelling men who are HIV-positive into HIV treatment programmes.
TABLE 2: Knowledge of male medical circumcision, HIV infection and reason for seeking male medical circumcision amongst clients.

\begin{tabular}{|c|c|c|}
\hline Variable & Frequency & Percentage \\
\hline \multicolumn{3}{|l|}{ Reasons for seeking MMC } \\
\hline Partial protection against HIV & 338 & 85.8 \\
\hline Social and/or Religious reasons & 30 & 7.6 \\
\hline Personal hygiene & 329 & 83.5 \\
\hline Others & 0 & 0.0 \\
\hline \multicolumn{3}{|l|}{ Benefits and advantages of MMC } \\
\hline Improved sexual performance & 8 & 2.0 \\
\hline Prevention of HIV transmission & 315 & 79.9 \\
\hline Reduce risk of STIs & 350 & 88.8 \\
\hline Cultural acceptability & 17 & 4.3 \\
\hline \multicolumn{3}{|l|}{ Knowledge about HIV } \\
\hline Yes & 390 & 98.5 \\
\hline No & 4 & 1.0 \\
\hline \multicolumn{3}{|l|}{ Knowledge about HIV } \\
\hline Sexual intercourse & 383 & 97.2 \\
\hline Blood transfusion & 358 & 90.9 \\
\hline Mother to child & 353 & 89.6 \\
\hline Sharing needles & 356 & 90.0 \\
\hline Hugging and kissing & 7 & 1.8 \\
\hline Others & 2 & 0.5 \\
\hline \multicolumn{3}{|l|}{ Previous VCT } \\
\hline Yes & 388 & 98.5 \\
\hline No & 4 & 1.0 \\
\hline Missing & 2 & 0.5 \\
\hline \multicolumn{3}{|l|}{ HIV status } \\
\hline Positive & 56 & 13.2 \\
\hline Negative & 337 & 85.0 \\
\hline Missing & 1 & 0.3 \\
\hline \multicolumn{3}{|l|}{ Duration of MMC healing } \\
\hline 1 day & 7 & 1.8 \\
\hline 1 week & 4 & 1.0 \\
\hline 2 weeks & 8 & 2.0 \\
\hline$>2$ weeks & 374 & 94.9 \\
\hline Missing & 1 & 0.3 \\
\hline \multicolumn{3}{|c|}{ Having sex whilst circumcision heals } \\
\hline Yes & 11 & 2.8 \\
\hline No & 381 & 96.7 \\
\hline Unsure & 1 & 0.3 \\
\hline
\end{tabular}

MMC, male medical circumcision; VCT, voluntary counselling and testing; HIV, Human Immunodefiency Virus; STI, sexually-transmitted infections.

TABLE 3: Effect of male medical circumcision and the risk of acquisition of HIV $(N=394)$.

\begin{tabular}{lll}
\hline Variable & Frequency & Percentage \\
\hline Effect of MMC on the risk of acquiring HIV & & \\
No effect & 11 & 2.8 \\
It increases the risk of acquiring HIV & 6 & 1.5 \\
It reduces the risk of acquiring HIV & 375 & 95.2 \\
Other & 1 & 0.3 \\
Missing & 1 & 0.3 \\
Whether risky sexual behaviour can remove the benefits of male circumcision & 340 & 86.3 \\
Yes & 35 & 8.9 \\
No & 18 & 4.6 \\
Unsure & 1 & 0.3 \\
Missing & 34 & 8.7 \\
Whether male circumcision protects women from being infected & with HIV \\
Yes & 347 & 94.9 \\
No & 11 & 11.0 \\
Unsure & 2 & 0.5 \\
Missing & 34 & \\
\hline
\end{tabular}

MMC, male medical mircumcision; HIV, Human Immunodefiency Virus. 


\section{Limitations}

This was a small study conducted at two sites in KwaZuluNatal. Because of the convenient nature of the sampling method, the results of this study may not be representative of the study population and may not be generalisable to other settings. The exclusion of clients younger than 18 years of age was a limiting factor as their experience and knowledge may be different from older clients.

\section{Recommendations}

More local studies are needed to gain a better understanding of the effect of MMC on sexual behaviour and to measure the impact of MMC on HIV transmission when it is incorporated into routine practice. There is also a need for research to be done amongst those under 18 years of age in order to determine their reasons for presenting for MMC and their knowledge of the benefits of MMC.

\section{Conclusion}

This study found that the average man presenting for MMC at these MatCH sites is young, lives in an urban township and is black, single and sexually active. Those presenting for MMC have excellent knowledge of the effects of circumcision on the transmission of HIV, were aware that MMC provides only partial protection, that condoms are still needed to prevent HIV and that the benefits of MMC can be reversed if condom use is not adhered to. Although the concerns about risk compensation are legitimate, most of the men in this study understood that condom use is still necessary post-circumcision. Circumcision presents an opportunity to educate young men about HIV prevention and to channel those who are positive into HIV treatment programmes.

\section{Acknowledgements Competing interests}

The author declares that he has no financial or personal relationship(s) that may have inappropriately influenced him in writing this article.

\section{References}

1. UNAIDS. Global report: UNAIDS report on the global AIDS epidemic 2013 [document on the Internet]. c2013 [cited 2014 Jan 15]. Available from: http:// www.unaids.org/en/media/unaids/contentasset/document/epidemiology/2013/ gr2013/UNAIDS_Global_Report_2013_en.pdf

2. UNAIDS. New data on male circumcision and HIV prevention: policy and programme implications [document on the Internet]. c2007 [cited 2014 Nov 02]. Available from: http://www.who.int/hiv/pub/malecircumcision/research_implications/en/

3. Bailey RC, Plummer FA, Moses S. Male circumcision and HIV prevention: Current knowledge and future research directions. Lancet Infect Dis. 2001;1(4):223-231. $\mathrm{http}: / / \mathrm{dx}$.doi.org/10.1016/S1473-3099(01)00117-7

4. Peters F, Marcus TS. Circumcision weeks: Making circumcision part of routine training and service delivery at district-level hospitals in South Africa. S Afr Fam Pract. 2011;53(3):262-266. http://dx.doi.org/10.1080/20786204.2011.10874096
5. Auvert B, Taljaard D, Lagarde E, et al. Randomized, controlled intervention trial of male circumcision for reduction of HIV infection risk: The ANRS 1265 Trial. PLoS Med. 2005;3(5):e226. http://dx.doi.org/10.1371/journal.pmed.0030226

6. Bailey RC, Moses S, Parker CB, et al. Male circumcision for HIV prevention in young men in Kisumu, Kenya: A randomised controlled trial. Lancet. 2007;369(9562):643656. http://dx.doi.org/10.1016/S0140-6736(07)60312-2

7. Gray RH, Kigozi G, Serwadda D, et al. Male circumcision for HIV prevention in men in Rakai, Uganda: A randomised trial. Lancet. 2007;369(9562):657-666. http:// dx.doi.org/10.1016/S0140-6736(07)60313-4

8. Tobian AA, Serwadda D, Quinn TC, et al. Male circumcision for the prevention of HSV-2 and HPV infections and syphilis. N Engl J Med. 2009;360(13):1298-1309. http://dx.doi.org/10.1056/NEJMoa0802556

9. Auvert B, Sobngwi-Tambekou J, Cutler E, et al. Effect of male circumcision on the prevalence of high-risk human papilloma virus in young men: Results of a randomized controlled trial conducted in Orange Farm, South Africa. J Infect Dis. 2009;199(1):14-19. http://dx.doi.org/10.1086/595566

10. Castellsaqué $X$, Bosch FX, Muñoz N, et al. Male circumcision, penile human papillomavirus infection, and cervical cancer in female partners. N Engl J Med. 2002;346(15):1105-1112. http://dx.doi.org/10.1056/NEJMoa011688

11. Ewings $P$, Bowie $C$. A case-control study of cancer of the prostate in Somerset and east Devon. Br J Cancer. 1996;74(4):661-666. http://dx.doi.org/10.1038/ bjc.1996.418

12. Morris B. Male circumcision guide for doctors, parents, adults \& teens [page on the Internet]. c2010 [cited 2014 May 12]. Available from: http://www.circinfo.net

13. Bateman C. Millions of snips will bolster our Health system. S Afr Med J. 2009;99(12);840-844.

14. Ncayiyana DJ. The illusive promise of circumcision to prevent femaleto-male HIV infection - not the way to go for South Africa. S Afr Med J. 2011;101(11):775-776.

15. Lagarde E, Dirk T, Puren A, et al. Acceptability of male circumcision as a tool for preventing HIV infection in a highly infected community in South Africa. AIDS 2003;17(1):89-95. http://dx.doi.org/10.1097/00002030-200301030-00012

16. Bridges JF, Selck FW, Gray GE, et al. Condom avoidance and determinants of demand for male circumcision in Johannesburg, South Africa. Health Policy Plan. 2011;26(4):298-306. http://dx.doi.org/10.1093/heapol/czq064

17. Westercamp M, Bailey RC, Bukusi EA, et al. Male circumcision in the general population of Kisumu, Kenya: Beliefs about protection, risk behaviors, HIV and STIs. PLoS One. 2010;5(12):e15552. http://dx.doi.org/10.1371/journal. pone.0015552

18. Goldstuck ND. Adult circumcision in the prevention of HIV/AIDS. S Afr Med J. 2014;104(1):17. http://dx.doi.org/10.7196/samj.7216

19. Terre Blanche $M$, Durrheim K, Painter D, editors. Research in practice: Applied methods for the social sciences. Cape Town: University of Cape Town; 2006.

20. Maternal, Adolescent and Child Health (MatCH). Male circumcision: Medical Case report form. Version 4.4 [document on the Internet]. n.d. [cited 2014 Aug 04]. Accessed from: www.match.org.za/publication [no longer available on site].

21. Connolly C, Simbayi LC, Shunmugam R, et al. Male circumcision and its relationship to HIV infection in South Africa: Results of a national survey in 2002. SAfr Med J. 2008;98(10):789-794.

22. Kelly R, Kiwanuka N, Wawer MJ, et al. Age of male circumcision and risk of prevalent HIV infection in rural Uganda. AIDS. 1999;13(3):399-405. http://dx.doi. org/10.1097/00002030-199902250-00013

23. IRIN. South Africa: Zulu king revives male circumcision [article on the Internet]. c2009 [cited 2013 Dec 01]. Available from: http://www.plusnews. org/report/87441/South Africa [updated 2014 Sep 28; available from: http://www.irinnews.org/report/87441/south-africa-zulu-king-revives-malecircumcision]

24. Ngodji TK. Knowledge, attitudes and practices of male circumcision for HIV prevention among voluntary counseling and testing clients in Onandjokwe District Hospital, Namibia [Master's thesis on the Internet; School of Public Health, Faculty of Community and Health Sciences, University of the Western Cape]. c2010 [cited 2014 Sep 28]. Available from: http://etd.uwc.ac.za/bitstream/ handle/11394/2576/Ngodji_MPH_2010.pdf?sequence=1

25. UNAIDS. New HIV report finds big drop in new HIV infections in South Africa [article on the Internet]. c2014 [cited 2014 Jan 30]. Available from http://www.unaids.org/en/resources/presscentre/featurestories/2014/ january/20140117southafrica/

26. Alsallaq RA, Cash B, Weiss HA, et al. Quantitative assessment of the role of male circumcision in HIV epidemiology at the population level. Epidemics. 2009;1(3):139-152. http://dx.doi.org/10.1016/j.epidem.2009.08.001

27. Nteta TP, Mokgatle-Nthabu M, Oquntibeju OO. Utilization of the primary health care services in the Tshwane region of Gauteng province, South Africa. PLoS One. 2010;5(11):e13909. http://dx.doi.org/10.1371/journal.pone.0013909

28. Statistics South Africa. Mid-year population estimates 2010 [document on the Internet]. c2010 [cited 2013 Aug 20]. Available from: http://www.statssa.gov.za/ publications/P0302/P03022010.PDF 